\title{
FINANCIAL REPORTING STANDARDS FOR THE PUBLIC SECTOR: NEW ZEALAND'S TWENTY-FIRST CENTURY EXPERIENCE
}

\author{
Carolyn J. Cordery* and Kevin Simpkins \\ Victoria University of Wellington
}

* Corresponding Author: Carolyn Cordery, School of Accounting and Commercial Law, Victoria University of Wellington, P O Box 600, Wellington, New Zealand. P: 644 463-5761; F: 644463 5076;

E: Carolyn.Cordery@vuw.ac.nz

Kevin Simpkins, School of Accounting and Commercial Law, Victoria University of Wellington, P O Box 600, Wellington, New Zealand. P: 644 463-9651; F: 644463 5076; E: Kevin.Sumpkins@vuw.ac.nz

Keywords: Public Sector Accounting, Standard-setting, Sector-neutral, Transaction-neutral

Version for Public Money and Management's special issue 13 April 2015.

Notes:

Professor Kevin Simpkins was directly involved in standard-setting, including having been Technical Director of the NZSA (1989-1993), a member of the FRSB from 1995-2002, the ASRB/XRB 2008-2014, and an IPSASB member 2000-2003. He was also Deputy Auditor-General from 2002-2005 and a member of the NFPSAC from 2006-2009. Associate Professor Carolyn Cordery has been a member of the NZASB since 2011 and was Chair of the NFPSAC from 2006-2010. The views expressed in this article are their own.

\footnotetext{
ABSTRACT

New Zealand was seen as world-leading when public sector financial reports were prepared using sector-neutral accounting standards from 1995 onwards. The decision in 2002 to adopt IFRS was disruptive, effecting new understandings of 'sector-neutral', and the standard-setter's approach was
} 
unsuccessful in meeting public sector users' needs. The development of a new strategy finalised in 2012 has created a multi-standards framework including adapted IPSASB standards applicable from 1 July 2014. While neutrality is still prized, it is within a framework of meeting users' needs. This paper traces the influences expediting these changes. 


\section{Financial Reporting Standards for the Public Sector: New Zealand's twenty-first century experience}

\section{Introduction}

Widely recognised as a key accountability mechanism, public sector financial reporting is a regular topic of debate in the pages of this Journal. Authors have discussed the move to accrual accounting (from cash) (e.g. Sutcliffe, 2003), the role of budgets and statistical reporting /national accounts (e.g. Heiling, Schührer, \& Chan, 2013; Jones, 2003), specific issues (such as standards adoption and infrastructure assets) (e.g. Grossi et al., 2009; Vass, 1990) and how accounting standards are set (e.g. Sutcliffe, 2003; Vass, 1990).

In recounting the move in New Zealand to require public sector organisations to report according to (adapted) International Public Sector Accounting Standards (IPSASs) from 2014, rather than (modified) International Financial Reporting Standards (IFRSs), this retrospective analysis of standard-setting in New Zealand seeks to highlight the primary influences operating between 2002 and 2012 which led to the decision to base public sector standards on IPSASs. While New Zealand is a specific context, general lessons from this experience can be applied to other jurisdictions seeking to develop or mandate standards for public sector reporting entities.

The article proceeds with a brief analysis of standard-setting in New Zealand, focusing specifically on the period from 2002 to 2012 . It does so, using a specific terminology to differentiate the term 'sector-neutral' as generally perceived in the different time periods. In the decade before 2002, a single set of accounting standards were developed (see below) as 'sector-neutral', when, "provisions for the public sector are interwoven with requirements for the private sector" (Baskerville \& Pont Newby, 2002, p. 2). In the following decade, for the single set of standards issued, 'sector-neutrality' became synonymous with 'transaction-neutrality', that is, "the idea that a transaction should be accounted for based on its underlying economic nature rather than on the type of entity undertaking it" (Lee \& Teixeira, 2004, p. 21) and was aspired to through a single set of standards with boxed text added for public benefit entities. ${ }^{1}$ Since the finalisation of a multi standards framework (in 2012), 'neutrality' continues to mean similar accounting for like

1 This was a similar process to that followed by the Australian Accounting Standards Board (AASB) after 2002 which used "the standards of the IASB as the "foundation" standards to which it adds material detailing the scope and applicability of the standard in the Australian environment. Additions are made, where necessary, broadening the context to cover those sectors not addressed by the IASB..." (Kevin Simpkins Advisory Services Ltd, 2006, p. 24). Indeed, Australia withdrew its three public sector accounting standards from 2005 to achieve this transaction neutrality. 
circumstances, but recognises that context cannot be ignored. Such standard-setting requires the balancing of fragmentation and specialisation (External Reporting Board (XRB), 2012).

\section{Overview of changes in New Zealand Standard-Setting 2002-2012}

New Zealand has enjoyed a long history of accounting standard-setting ${ }^{2}$, which can be traced back to the early 1960's project initiated to develop Recommendations on Standards of Best Accounting Practice (Accountants Journal, July 1962, p.374 cited in Keenan, 2000, p. 100). Bradbury (1999) suggests New Zealand first adopted English standards 'wholesale', but the need to modify these to the local context quickly emerged. From the 1960s, and until the passage of the first Financial Reporting Act in 1993 (FRA93), the development and issuance of accounting standards was the sole preserve of New Zealand's professional accounting body, the New Zealand Society of Accountants (NZSA). ${ }^{3}$ From 1992, standard-setting for both the public and private sectors was carried out by the Financial Reporting Standards Board (FRSB) of the NZSA (Warren, 2004). This board was voluntary, comprising NZSA members, and was supported by a small staff (Bradbury \& van Zijl, 2007). In 1993 a new Accounting Standards Review Board (ASRB) established under the FRA93 as an independent Crown Entity was authorised to approve (but could not develop) accounting standards developed by the FRSB or other parties, following which those standards had legal force. In practice only standards submitted by the FRSB were ever approved. One problem with this structure was that neither of the two accounting standards boards exercised explicit authority for financial reporting strategy (XRB, 2012). Further, while the ASRB comprised knowledgeable members appointed by the relevant Minister (FRA93, s. 23(3)), it was a part-time board, with no employees (contracting in its secretariat and accountant), and met only a few times a year (Office of the Auditor-General, 2009). The two tier structure (of the FRSB and the ASRB) was maintained until 1 July 2011 when a reconstituted ASRB (renamed the XRB), assumed full responsibility for development, approval and issuance of accounting standards, and was given explicit responsibility for financial reporting strategy (FRA93, 2010).

While a small country with limited resources available for standard-setting, New Zealand has always played an active and significant role in the international standard-setting community. New

2 By this we are referring to standard-setting in broadly the form that we understand it today.

3 Subsequently the New Zealand Institute of Chartered Accountants and, from the 2014 merger with the Institute of Chartered Accountants Australia, has become Chartered Accountants Australia and New Zealand. The term 'NZSA' is used throughout this article. 
Zealand was an associate member of the International Accounting Standards Committee from 1974, just a few months after its inception and, despite its small size, was an active player in various other groupings such as the G4+1 group of standard-setters, which it joined from 1996 until the establishment of the International Accounting Standards Board in 2001 (Malthus, 2004).

The NZSA was also a leader in the development of accounting for public sector entities, establishing a Public Sector Accounting Committee in 1986, which emanated from the public sector working group established in 1981 (Warren, 2004). This committee developed a Statement of Public Sector Accounting Concepts and an initial standard, followed by technical guidance bulletins on a number of topics, although these were far short of a full public sector suite. Subsequent to major changes in the New Zealand Government's accounting after the passage of the Public Finance Act 1989, the NZSA published a major package of seven exposure drafts in 1991. This package proposed a new Explanatory Foreword to General Purpose Financial reporting (ED-59), a Statement of Concepts for Financial Reporting (to apply to all sectors) (ED-60), a Public Sector Interpretation to that Statement (ED-61) ${ }^{4}$, a framework and specific application proposals on differential reporting (ED-62 and 63), and the first of two new standards which would apply to all entities in the private and public sectors (ED-64 and 65) (FRSB, 1993). Not only were future standards to be sector-neutral, but past standards were also to be revised to be sector-neutral (Anonymous, 1993). Following the promulgation of these exposure drafts as standards (except for ED-61), the Public Sector Accounting Committee pronouncements were withdrawn. So began a period of sector-neutral standard-setting which was to continue until the announcement in 2002 that New Zealand would adopt IFRS across all sectors.

This decade's sector-neutral approach was world-leading and New Zealanders were very committed to, and very proud of the success of the approach. There were issues - including two standards taking almost a decade to finalise (Baskerville \& Pont Newby, 2002). ${ }^{5}$ Baskerville and Pont Newby (2002, p. 20) also described a failure in the due process of a particular standard and, partly foreshadowing developments five years later, suggested that with respect to sector-neutral standard-setting "debate to date has largely overlooked the preferences of the stakeholder group most likely to be affected by sector-neutrality: that is, account preparers in the public sector".

4 Interestingly ED-61 was never finalized. Submissions on the exposure draft resulted in a decision that the document was not needed but that some of its content should be added to the Statement of Concepts for Financial Reporting (the Conceptual Framework).

5 Accounting for Business Combinations and Accounting for Property, Plant and Equipment. 
New Zealand's sector-neutral experience also contributed directly to development of IPSASs. Ian Ball, Central Financial Controller in the New Zealand Treasury during the public sector reforms and a member of the FRSB and ASRB, was appointed a member of the IFAC Public Sector Committee (PSC) in 1993, becoming Chairman in 1995. He led the PSC to develop accounting standards for governments and other public sector entities, chairing the PSC until the first standards had been issued in 2000. The PSC became the IPSASB in 2004, continuing its standard-setting work. New Zealand representatives have served on the IPSASB to the present day.

As noted, international standards had often been a starting point for the development of New Zealand standards (Bradbury, 1999). While previously they were modified to suit the New Zealand context generally, following 1993, when the same set of standards were to be applied to all entities, they were also modified to be sector-neutral. Nevertheless, in 1997 the FRSB (at that time the standards development board) decided to harmonise with International and Australian accounting standards, ${ }^{6}$ issuing the first two exposure drafts under that approach in 1999 (Bradbury, 1999). ${ }^{7}$ From then on, any significant differences or issues between the standards were to be highlighted in the exposure drafts prior to the standards' issuance (Bradbury, 1999).

A further step in international harmonisation was evidenced in an FRSB exposure draft (ED92) in June 2002, which proposed that New Zealand standards would be developed from international standards and that departures would be made only in rare and exceptional circumstances. While ED-92 remained on issue, Australia decided to adopt international accounting standards with effect from January 2005. ${ }^{8}$ This caused an urgent re-think in New Zealand (especially given the impetus to harmonise with Australian and international standards), leading to the announcement by the ASRB on 21 October 2002, following a recommendation from the FRSB, of an in-principle decision that listed entities in New Zealand should be required to comply with IFRSs by 2007 (ASRB, 2002a). The announcement acknowledged that issues for the public sector would require special attention in the future. On 19 December 2002, the ASRB announced that, following consultation, it intended to broaden the scope of its earlier announcement and extend the

6 Those standards were still modified for unique factors arising in New Zealand, including the broader application of the standards to all entities.

7 ED-86 "Provisions, Contingent Liabilities and Contingent Assets", and ED-87 "Accounting for Intangible Assets".

8 Bradbury and van Zijl (2007) notes that the Financial Reporting Council (the Australian strategy-setter) instructed the AASB to do so and that it was 'a surprise'. There was no consultation with constituents, least of all New Zealand. 
requirement to apply IFRS to the public sector (ASRB, 2002b). A significant issue in the ASRB's consultation was whether and, if so, how 'adopted' standards could also apply to public sector entities. The belief was that "the financial reporting requirements of profit-oriented and public benefit reporting entities will stay closely aligned" (Teixeira \& Warren, 2003, p. 8), although this evidenced a shift in the meaning of sector-neutrality - the aspiration was that standards would now be transaction-neutral, with the sectors delineated where necessary in the standard-setter's statements.

All New Zealand entities required to comply with accounting standards were permitted to adopt a platform of New Zealand equivalents to IFRS for periods commencing 1 January 2005, being required to do so from 1 January 2007 (ASRB, 2002b). The ASRB (2002a) acknowledged that major concerns about this proposal had come from the public sector. The FRSB and ASRB thereafter adopted a distinction between profit-oriented entities and public benefit entities (PBEs) as an essential part of retaining a single set of accounting standards, but with PBE differences included in those standards. ${ }^{9}$ These requirements were different from those in Australia for public sector entities (XRB, 2012) (for example, Australia sought to harmonise its requirements with Government Finance Statistics; Kevin Simpkins Advisory Services Ltd, 2006). ${ }^{10}$

Despite concerns, the ASRB (2002a) announced "strong support for continuing to have a single set of sector-neutral standards", although the prior practice of (one set of) sector-neutral accounting standards had in fact come to an end. This was evident when the ASRB conceded that additional measurement and recognition requirements (to deal with public sector issues on which IFRSs were silent) should be inserted in 'boxed text' and specific 'public-sector-only' paragraphs (Bradbury \& van Zijl, 2007), and the standard-setters exhibited an overriding concern to maintain the 'purity' of IFRSs. Much of the useful interpretation guidance for public sector entities which had previously been intertwined in the single set of accounting standards was lost in the changeover to IFRS equivalents (Bradbury \& Baskerville, 2008). However, the possibility of adopting a separate set of public sector standards received scant consideration - the focus was on how a single set of standards could be maintained. The IPSASB had issued only seventeen standards by the end of 2001

9 One area of difference mentioned by Teixiera and Warren (2003) was that IAS 36 used cash generating assets as the basis for impairment assessment and did not recognize that public sector entities may have non-cash generating assets.

10 For a discussion of the differences between accounting standards, budgeting and statistical standards, see Jones (2003) and Heiling et al. (2013). 
and, with a lengthy list yet to develop (Sutcliffe, 2003), the IPSASs did not constitute a body of standards which could be adopted; and there was no consideration of that possibility.

While a range of different concerns were raised about the application of New Zealand equivalents to IFRSs to public sector entities between 2002 and 2007, the issues came increasingly to light in 2007 when adoption was required. Significant concerns were raised by the then AuditorGeneral, Kevin Brady (2007). Brady's subsequent report to Parliament (Office of the AuditorGeneral, 2009) detailed his concerns with the accounting standard-setting process. His Office had always been a significant contributor to this process, but he withdrew his staff from the FRSB and its public benefit sub-committee from 2008 in protest about the lack of traction on public sector issues (Office of the Auditor-General, 2009). ${ }^{11}$ The Not-for-Profit Sector Advisory Committee (NFPSAC) of NZICA (2009) also raised a number of concerns about the application of the IFRS-based standards to not-for-profit (NFP) entities in the private sector.

In September 2009, the (then) Ministry of Economic Development (MED) published a Discussion Paper "The Statutory Framework for Financial Reporting" which considered the circumstances under which the law should impose requirements on entities to prepare, publish and obtain assurance on General Purpose Financial Reports (GPFR) (MED, 2009). The ASRB simultaneously published a Discussion Document on "Proposed Application of Accounting and Assurance Standards under the Proposed New Statutory Framework for Financial Reporting" which outlined the Board's tentative proposals on the accounting standards to be used by entities required to prepare GPFR under the MED Document. The ASRB proposed a multi-standards framework with IFRS-based standards for profit-oriented entities, IPSAS-based standards for public sector public benefit entities, and an IPSAS-based "NFP Application" for NFP public benefit entities (ASRB, 2009). This proposal signalled a third version of neutrality, one in which like transactions in like circumstances should be accounted for in the same way, but one in which context (and the users in that context) cannot be ignored.

By 2011 the ASRB had concluded that a multi-standards approach was necessary if accounting standards were to meet the needs of the various users of financial reports. This decision and proposed approach was endorsed by the $\mathrm{XRB}^{12}$ at its first meeting on 1 July 2011. In September

11 This effectively further reduced public sector input to the standard-setting process, with the Treasury providing the only remaining public sector representative to the FRSB.

12 The ASRB was renamed the XRB with six ASRB members being reappointed along with the appointment of three new members. In addition, new strategic and operational obligations were imposed as discussed. 
2011 the XRB's (2011) position paper “Accounting Standards Framework: A Multi-Standards Approach" explained its decision. It issued two further consultation papers contemporaneously on the implementation of the frameworks for profit-oriented entities and public benefit entities respectively. Following further deliberations and, as required by a 2011 amendment to the FRA93, it submitted "Proposals for the New Zealand Accounting Standards Framework Incorporating the Draft Tier Strategy" to the Minister of Commerce on 22 March 2012 (XRB, 2012). The Minister approved that document on 2 April 2012. ${ }^{13}$ Issuance of the standards for different entities under that Strategy document occurred between 2012 and 2014. Figure 1 shows a summary of these events.

The foregoing discussion leads to the question we explore in this paper: What were the primary influences affecting New Zealand's decisions on the approach to setting standards for different sectors between 2002 and 2012?

[INSERT FIGURE 1 ABOUT HERE]

\section{Influences on Standard-Setting}

This brief history evidences a number of changes, therefore two main influences and relevant literature are explored: the impact of standard-setting structure (particularly strategy) and political forces on these standard-setting decisions. The issue of sector-neutrality is also considered.

\subsection{Standard-setting structures}

As has already been noted, UK and Australian standards were adopted and adapted in New Zealand (Keenan, 2000); it therefore could be expected that these countries would provide guidance on standard-setting structure. In the UK and Australia the profession had been replaced as the standard-setter following crises and non-compliance issues in the 1970s and 1980s (Vass, 1990; Walker, 1987). Their respective governments sought to more closely control standard-setting, rather than allowing the profession to dominate, or the private sector to develop standards (Vass, 1990; Walker, 1987). Further, there was a push (in Australia at least) for accounting standards to have the force of law, as well as for community participation in standard-setting activities (Walker,

13 Section 34D of the FRA93 applied (XRB, 2012). 
1987). ${ }^{14}$ In New Zealand, similar pressures led the government to establish the ASRB under the FRA93 but, rather than reducing the authority of the FRSB, Keenan (2000, p. 109) stated that the NZSA enjoyed "significantly enhanced regulatory authority" as a result of the move. Accounting standards received legal backing (likely increasing compliance), but the government was unprepared to provide sufficient financial support to enable the part-time ASRB to develop and progress a strategic plan for the structure of accounting standards, or to undertake broad consultative activities; therefore the majority of standard-setting activities remained with the FRSB of the NZSA (XRB, 2012; Keenan, 2000).

Yet, standard-setting strategy is necessary: as to whether the package of accounting standards is appropriate, whether compliance costs and benefits are being managed appropriately, and whether users' needs are being met (XRB, 2012). Brusca, Montesinos and Chow (2013) provide an example of strategy in their recent analysis of the IPSASB. While IPSASB was in a weak position when New Zealand chose to adopt IFRS, its growing legitimacy is due to its strategic "efforts to adapt to the environment and the profession" as well as growing its membership (Brusca et al., 2013, p. 439).

To the extent that national standard-setters have a strategy, it is commonly singular: for example, to harmonise with IFRS. This reduces the likelihood of alternatives being considered despite Buhr (2012, p. 300) noting the "ongoing challenge with using IFRS as a starting point because these are developed for the private sector alone, and do not deal with governments or not-for-profit organisations". Indeed, while the UK retains a single strategy (to adopt IFRS), authors such as Connolly and Wall (2012) are negative about the long-term implications of the UK applying IFRS in the public sector, due to the complexity of the budgetary framework and the need for public sector preparers to make relevant disclosures and understand how to adapt IFRS language to the public sector.

Standard-setting strategy was instrumental in the 2011 New Zealand reform, with the XRB being statutorily responsible for establishing and implementing a strategic framework (for assurance and accounting). Whilst the XRB acknowledges that it is most cost-efficient if New Zealand can adopt credible international standards (XRB, 2012), its track record to date shows that it is prepared to make major short-term changes for longer term benefits. Further, it utilises separate sub-boards

14 However, Walker (1987) notes the failure of Australia's ASRB which operated from 1984-6. 
to undertake the technical role of standard-setting, allowing it to monitor their success and environmental change. ${ }^{15}$ It retains the strategy responsibility itself.

In addition, the XRB promotes itself as "a listening organisation", eliciting constituents" views through a large number of public meetings and working groups, as well as through receiving formal submissions (Sinclair \& Bolt, 2013). Whilst Sinclair and Bolt (2013) summarise efforts the XRB has made in the NFP space, a perusal of past minutes of the XRB and its sub-boards show numerous consultations, the foundation of a widely representative and independently chaired External Reporting Board Advisory Panel (XRAP) and, associated with its sub-board (the NZASB) a Technical Reference Group, in order to understand accounting standards issues across all sectors. ${ }^{16}$

\subsection{Political Forces in Standard-setting}

New Zealand's public sector accounting history also shows the impact of political forces on standardsetting. While government is not directly implicated in directing the speed of reform (as Jones \& Lüder, 2011 found it was in Germany), a number of key players forced the government's hand. Publically (through the Chartered Accountants Journal), the Auditor-General (Brady, 2007, p. 19) stated that the IFRS as adapted in New Zealand had "not much relevance... [and] the reporting issues of most relevance to the public sector are not being addressed". He continued by noting that the FRSB was not considering users' needs sufficiently and instead focusing on technical answers which were very focused on measuring future cash flows for decision-making, rather than seeking to assist the discharge of accountability. He predicted there would be increasingly strident calls for separate accounting standards to meet users' needs, especially given the high costs that had been experienced in adopting IFRS in the public sector (Brady, 2007). ${ }^{17}$

The Chair of the FRSB and Technical Director argued in the same Journal issue that such opinions were likely to be related to the initial 'pain' of adoption of new standards, that the standards were of high quality and that there would always be different views on the 'right' technical answer (Perry \&

15 These are the New Zealand Accounting Standards board (NZASB) and New Zealand Auditing and Assurance Standards Board.

16 These can be seen on the website www.xrb.govt.nz, as can the policy for adapting standards for the public sector. This policy is necessary as the public sector suite includes adapted IFRS and old standards to fill gaps in IPSASs.

17 High costs were also experienced in the UK, which needed to delay the public sector adoption of IFRS (Connolly \& Wall, 2012). Connolly and Wall (2012) recounted the high number of challenges met by UK adopters, and these were evident in New Zealand's earlier experience, especially with the 'one-off' costs of convergence with new standards (Teixeira \& Pickens, 2004). 
Crook, 2007). The Auditor-General's (2009, p. 5) rejoinder - a full report to Parliament - noted his disappointment with "the overall quality of financial reporting standards applying to most entities in the public sector" and argued that the approach to standard-setting must change to meet users' needs. He did not consider that his views (expressed over six years or more) were being heard, and wanted Parliament to be aware of and action his concerns. ${ }^{18}$ Parliament's Commerce Committee (2009) noted that Parliament's Finance and Expenditure Committee met and discussed these with him in 2008. Further, in conducting its financial review of the ASRB, Parliament's Commerce Committee (2009, p. 4) also reviewed New Zealand's financial reporting framework, noting:

We agree ... that the Auditor-General's discussion paper may signal that it is time to reconsider whether a sector-neutral approach remains appropriate. .. [that] international public sector standards have now developed to the point where there may be benefit in adopting them. This might address some of the issues raised in the Auditor-General's report, although possibly not all, as it will be a matter of assessing what is realistically achievable."

This was a strong signal for the future of accounting standards in New Zealand, despite the fact that, as an independent Crown Entity, the ASRB was required to and did make its own strategic and other decisions.

\subsection{Sector-neutrality: a 'glass-half-full' or a 'glass-half-empty'?}

As noted, three distinct perspectives of 'sector-neutrality' can be observed. With the decision to adopt IFRS in 2002, New Zealand's sector-neutrality (the aim that all entities could use the same standards) ceased (XRB, 2011). Nevertheless, we argue that the standard-setters aspired to a 'transaction-neutral' position post-2002, celebrating what had been achieved and confident that problems could be remediated. For example, Lee and Teixeira $\left(2004\right.$, p. 21) ${ }^{19}$ suggested sectorneutrality could be achieved, that "we do observe absence of neutrality even within profit-oriented entities", and that IFRS would remedy this as well as cater to the public sector. This aspirational position perceives the search for neutrality as a 'glass-half-full' and may reflect the strong push since the development of New Public Management for profit-oriented standards to be applied to public sector accounting (Vass, 1990). At a pragmatic level, this sector-neutrality is a desire to have 'one set' of accounting standards, with requirements as similar as possible, leading to greater comparability and understandability and also ease of skill transfer between different sectors (Kevin Simpkins Advisory Services Ltd, 2006).

18 Others also noted problems with the IFRS adaptations (for example, NFPSAC, 2009; Warren, 2004).

19 Simon Lee and Alan Teixeira were then staff of the NZSA and FRSB. 
However, the Auditor-General's (2009) critique is an indication that others focused instead on the difficulties with "language, application and accounting treatments" in the adapted IFRS (XRB, 2011, p. 9). Indeed, Ken Warren (2004, p. 28) (later New Zealand's IPSASB member) noted that the 2002 decision placed New Zealand at a "crossroads" as: "the IASB - is only concerned about profitoriented entities operating in international markets. Its agenda, priorities and sometimes its decisions cannot be guaranteed to meet the needs of public sector constituents". This position of considering deficits in accounting standards-setting, could be called a 'glass-half-empty' viewpoint, where insufficient attention to public-sector-specific issues is highlighted. Such critiques come from those who believe that the public sector has differences when compared to the private sector (Kevin Simpkins Advisory Services Ltd, 2006). Overseas examples include calls for a conceptual framework sympathetic to public sector concepts not encountered in the private sector, and for changes to profit-oriented standards when being applied in a public sector context (Chan, 2012; Connolly \& Wall, 2012; Rutherford, 1990). Commonly these concerns arise when standards are based upon "technical 'principles' with poor, if any, links to the use made of the financial statements..." (Rutherford, 1990, p. 14).

Nevertheless, many would suggest that the differences between sectors are not that great and may relate more to display and disclosure than technical issues (Kevin Simpkins Advisory Services Ltd, 2006). Indeed, even during the New Zealand reform, only "around $48 \%$ of respondents supported a multi-standards approach, $25 \%$ supported a single-standards approach, $24 \%$ expressed no view and $3 \%$ were equivocal" (XRB, 2011, p. 8). The XRB (2011, p. 8) suggested that "the degree of support for a sectoral-specific approach appeared to be correlated to the extent to which the current framework was viewed as meeting or not meeting particular respondents' needs" and that, in New Zealand, the NFP sector were most likely to support a multi-standards approach. Yet, the move to a multi-standards framework recognises users' needs differ between sectors, that some issues in the public and NFP sectors require different accounting, but that like transactions in like circumstances should ideally be accounted for in a neutral way.

\section{Conclusion}

The New Zealand experience was that it was not possible to retain pure IFRS and also meet the needs of other entities - the preparers and users. As it approached the decision to adopt IFRS in 2002 , there was little time to consider the many issues arising and, given the prior sector-neutral approach to developing standards from an international base, a decision to adopt IFRS seemed a natural choice. It remains apparent that profit-oriented preparers and users were reasonably 
satisfied with IFRS and saw sector-neutrality as a 'glass-half-full' with the potential for convergence, but that many public and NFP sector preparers and users observed what was lacking in these profitoriented standards and thus observed a 'glass-half-empty'. While 2015 marks the first year in which GPFR are being prepared under the multi-standards framework, to date the process has been generally well-supported. 


\section{Legislation}

Financial Reporting Act (FRA93) (1993).

\section{References}

Accounting Standards Review Board. (2002a). ASRB recommends compulsory adoption of International Financial Reporting Standards. Wellington, New Zealand: Accounting Standards Review Board.

Accounting Standards Review Board. (2002b). NZ could comply with Interantional Financial Reporting Standards as early as 2005. Wellington, New Zealand: Accounting Standards Review Board.

Accounting Standards Review Board. (2009). Proposed Application of Accounting and Assurance Standards under the Proposed New Statutory Framework for Financial Reporting. Wellington: Accounting Standards Review Board.

Anonymous. (1993). Technical Committees Restructured. Chartered Accountants Journal, 72, 1, pp. 57-58.

Baskerville, R. F., \& Pont Newby, S. (2002). Due Process Failure In Sector-Neutral Accounting Standard-Setting. Financial Accountability \& Management, 18, February, pp. 1-23.

Bradbury, M. E. (1999). Harmonising with overseas accounting standards. Chartered Accountants Journal, 78, 6, pp. 5-11.

Bradbury, M. E., \& Baskerville, R. F. (2008). The "NZ" in "NZ IFRS": Public Benefit Entity Amendments. Australian Accounting Review, 18, 3, pp. 185-190.

Bradbury, M. E., \& van Zijl, T. (2007). International Financial Reporting Standards and New Zealand: Loss of Sector Neutrality. Research in Accounting Regulation, 19, 6, pp. 35-51.

Brady, K. (2007). Do NZ IFRS meet the public sector's needs ? Chartered Accountants Journal, 86, 10, pp. 19-21.

Brusca, I., Montesinos, V., \& Chow, D. S. L. (2013). Legitimating International Public Sector Accounting Standards (IPSAS): the case of Spain. Public Money \& Management, 33, 6, pp. 437444.

Buhr, N. (2012). Accrual accounting by Anglo-American governments: Motivations, developments, and some tensions over the last 30 years. Accounting History, 17, 3-4, pp. 287-309.

Chan, J. L. (2012). Government Accounting: An Assessment of Theory, Purposes and Standards. Public Money and Management, 23, 1, pp. 13-20.

Commerce Committee. (2009). 2008/09 financial review of the Accounting Standards Review Board. Wellington, New Zealand: House of Representatives. 
Connolly, C., \& Wall, A. (2012). Implementing IFRSs in the public sector: caveats from a case in the UK. Public Money \& Management, 32, 1, pp. 53-60.

External Reporting Board. (2011). Accounting Standards Framework: A multi standards approach. Wellington: External Reporting Board.

External Reporting Board. (2012). Proposals for the New Zealand Accounting Standards Framework. Retrieved from http://xrb.govt.nz/includes/download.aspx?ID=120683

Financial Reporting Standards Board. (1993). Promulgations. Chartered Accountants Journal, 72, 7, pp. 76-77.

Grossi, G., Newberry, S., Bergmann, A., Bietenhader, D., Tagesson, T., Christiaens, J., ... Rommel, J. (2009). Theme: Whole of government accounting - international trends. Public Money \& Management, 29, 4, pp. 209-218.

Heiling, J., Schührer, S., \& Chan, J. L. (2013). New development: Towards a grand convergence? International proposals for aligning government budgets, accounts and finance statistics. Public Money \& Management, 33, 4, pp. 297-303.

Jones, R. (2003). Measuring and Reporting The Nation's Finances: Statistics and Accounting. Public Money and Management, 23, 1, pp. 21-28.

Jones, R., \& Lüder, K. (2011). The Federal Government of Germany's circumspection concerning accrual budgeting and accounting. Public Money \& Management, 31, 4, pp. 265-270.

Keenan, M. G. (2000). Between anarchy and authority: the New Zealand Society of Accountants' management of crisis, 1989-1993. Accounting History, 5, 2, pp. 93-119.

Kevin Simpkins Advisory Services Ltd. (2006). A Review of the Policy of Sector-Neutral Accounting Standard-Setting in Australia: Report to Australian Financial Reporting Council. Wellington, New Zealand.

Lee, S., \& Teixeira, A. (2004). Implications of IFRS for sector-neutral standard setting. Chartered Accountants Journal, 83, 6, pp. 21-24.

Malthus, S. (2004). International Convergence of Financial Reporting. WEOrking Paper, Nelsom Marlborough Institute of Technology, Nelson.

Ministry of Economic Development. (2009). The Statutory Framework for Financial Reporting: Discussion Document. Retrieved from www.med.govt.nz

Not-for-Profit Sector Advisory Committee. (NFPSAC) (2009). Not-for-Profit Sector Advisory Committee Position Paper. Wellington: New Zealand Institute of Chartered Accountants.

Office of the Auditor-General. (2009). The Auditor-General's views on setting financial reporting standards for the public sector. Wellington: Office of the Auditor General. 
Perry, J., \& Crook, K. (2007). Financial reporting standards for public sector entities. Chartered Accountants Journal, 86, 10, pp. 22-24.

Rutherford, B. (1990). Towards a conceptual framework for public sector financial reporting. Public Money \& Management, 10, 2, pp. 11-15.

Sinclair, R., \& Bolt, R. (2013). Third Sector Accounting Standard Setting: Do Third Sector Stakeholders Have Voice? Voluntas: International Journal of Voluntary and Nonprofit Organisations, 24, 3, pp. 760-784.

Sutcliffe, P. (2003). The standards programme of IFAC's Public Sector Committee. Public Money \& Management, 23, 1, pp. 29-36.

Teixeira, A., \& Pickens, D. (2004). Global FRS: risks and strategies. Chartered Accountants Journal, 83, 1, pp. 18-20.

Teixeira, A., \& Warren, K. (2003). Developing New Zealand-relevant IFRS. Chartered Accountants Journal, 82, 6, pp. 8-10.

Vass, P. (1990). Accounting standards and the public sector. Public Money \& Management, 10, 2, pp. 17-22.

Walker, R. G. (1987). Australia's ASRB: a Case study of Political Activity and Regulatory Capture. Accounting and Business Research, 17, 67, pp.269-286.

Warren, K. (2004). At the crossroads. Chartered Accountants Journal, 83, 6, pp. 26-29. 
Figure 1: Timeline of Changes in New Zealand Standards Setting 2000-2013.

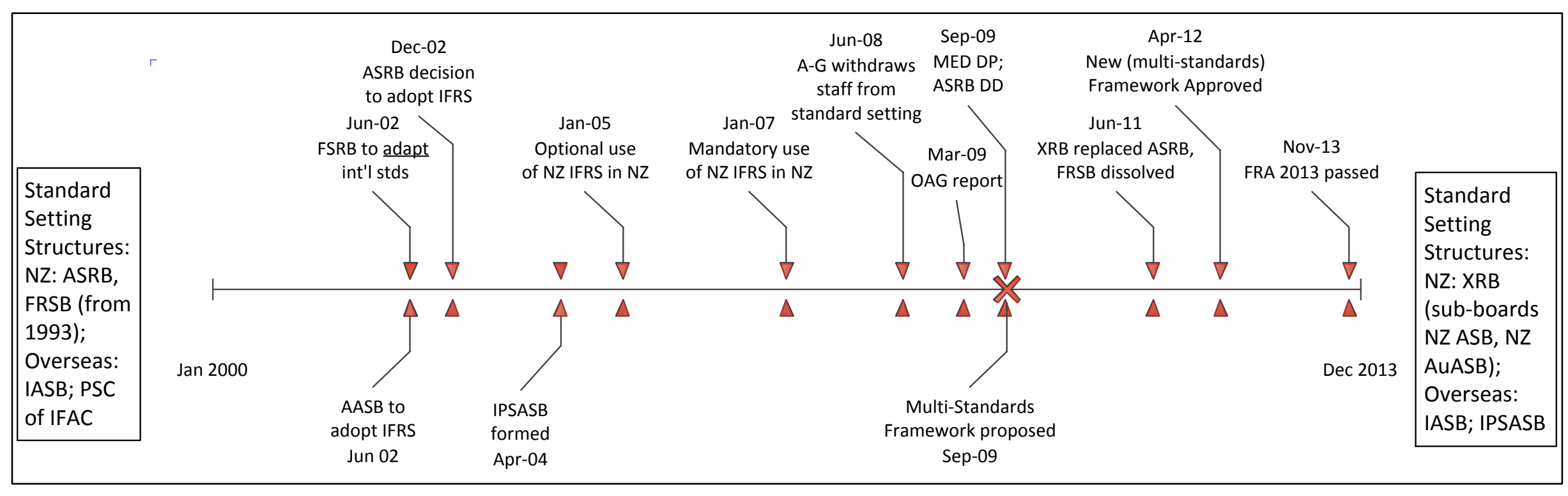

